\title{
USULAN STRATEGI UNTUK MENINGKATKAN DAYA SAING PRODUK MEBEL ROTAN SINGLE CHAIR DENGAN ANALISIS RANTAI NILAI (Studi Kasus : Klaster Mebel Rotan Kab. Cirebon)
}

\author{
Ary Arvianto, Arien Dewi Rakhmawati \\ Program Studi Teknik Industri Universitas Diponegoro Semarang \\ Jl. Prof Sudarto, SH., Semarang \\ aryarvi@yahoo.com, arieneira_dr@yahoo.com
}

\begin{abstract}
Abstrak
Industri mebel rotan merupakan salah satu andalan sektor industri di Indonesia dimana sentra pengolahan rotan terbesar adalah di Kabupaten Cirebon, Jawa Barat. Namun, terdapat beberapa kendala dalam industri mebel rotan di Cirebon ini diantaranya semakin ketatnya persaingan antar produsen dunia dan kebijakan pemerintah memperbolehkan ekspor rotan yang menyebabkan keuntungan di pihak negara pesaing Oleh karena itu, dibutuhkan suatu strategi untuk meningkatkan daya saing produk rotan di pasar dunia. Strategi ini dapat diperoleh dengan melakukan analisis value chain. Tujuan dari penelitian ini adalah untuk menganalisis rantai nilai produk mebel rotan dan mendapatkan strategi kompetitif yang tepat untuk diterapkan oleh setiap pelaku rantai nilai. Metode yang dilakukan adalah analisis finansial, analisis SWOT, analisis Competitiveness Diamond, dan analisis Critical Success Factor (CSF). Objek penelitian adalah perusahaan-perusahaan yang merupakan anggota dari Asosiasi Pengusaha Mebel Indonesia (ASMINDO) Cirebon yang memproduksi mebel rotan single chair. Dari hasil pengolahan data dan analisis diperoleh hasil bahwa strategi yang dapat diterapkan di pihak supplier dalam hal ini pengumpul adalah mendirikan anak perusahaan di tempat tersedia bahan baku dan melakukan merger dengan perusahaan. Strategi yang dapat diterapkan di pihak perusahaan adalah menerapkan upah tenaga kerja per unit produk yang dihasilkan, pengalokasian dana untuk promosi, memprioritaskan buyer langganan, sharing informasi dan inovasi dengan buyer, memiliki fleksibilitas yang tinggi dalam hal kualitas dan harga, bekerjasama dengan asosiasi dan pemerintah dalam kegiatan pameran, dan melakukan merger dengan perusahaan lain ataupun dengan supplier. Sedangkan strategi yang dapat diterapkan di pihak buyer dalam hal ini wholeseller adalah menurunkan harga produk, memaksimalkan promosi dan menjaga hubungan baik dengan perusahaan yang sudah menjadi kepercayaan.
\end{abstract}

Kata Kunci: mebel rotan, value chain, strategi, ASMINDO Cirebon

\begin{abstract}
Rattan furniture industry become one of the leading sector in Indonesia where the biggest rattan processing center palced in Cirebon, West Java. However, there are some constraints in rattan furniture industry in Cirebon which include the increasing of competition among global manufacturers and the government policy that allowed rattan export lead to profits in the competing countries.Therefore, we need a strategy to enhance the competitiveness of rattan products in world markets. This strategy can be obtained by analyzing the value chain. The purposes of this study are to analyze the value chain of rattan furniture products and get the appropriate competitive strategy to be implemented by each actor within value chain. The method is carried out financial analysis, SWOT analysis, Diamond Competitiveness analysis, and analysis of Critical Success Factor (CSF). Object of research are companies which are members of the Association of Indonesian Furniture (ASMINDO) Cirebon that produced single chair rattan. From the results of data processing and analysis, the strategies that can be applied in suppliers are to establish a subsidiary in the available raw materials and merged with the company. The strategies that can be applied in the company are applying its labor costs per unit of product produced, the allocation of funds for promotion, buyers prioritize subscriptions, sharing information and innovation with the buyer, has a high flexibility in terms of quality and price, collaborate with associations and government in exhibitions, and merged with another company or with suppliers. While strategies that can be applied in buyer in this case wholeseller are to lower the price of the product, maximize promotion and maintaining good relationships with companies that already trusted
\end{abstract}

Keywords: rattan furniture, value chain, strategy, ASMINDO Cirebon

J@TI Undip, Vol VIII, No 2, Mei 2013 


\section{PENDAHULUAN}

Rotan merupakan komoditas Hasil Hutan Bukan Kayu atau HHBK yang potensial di Indonesia. Kurang lebih 85\% produksi rotan dunia berasal dari Indonesia (http://dishut.jabarprov.go.id). Oleh karena itu, industri mebel rotan menjadi andalan industri mebel di Indonesia. Salah satu yang menjadi tempat pengolahan rotan terbesar di Indonesia adalah di Kabupaten Cirebon, Jawa Barat. Namun setelah tahun 2005 industri mebel ini mengalami penurunan jumlah produksi yang dipicu oleh kebijakan pemerintah membuka kran ekspor rotan dan akibat dari persaingan dengan China dan Vietnam. Beberapa industri yang masih bertahan adalah perusahaan-perusahaan yang merupakan anggota dari Asosiasi Pengusaha Mebel Indonesia (ASMINDO). Berdasarkan hal-hal tersebut maka dibutuhkan suatu strategi yang dapat membuat produk mebel rotan Indonesia khususnya untuk klaster Cirebon. Strategi ini dapat ditemukan dengan menganalisis keseluruhan aktifitas-aktifitas yang terjadi diantara pelaku-pelaku yang berperan dalam penambahan nilai produk mebel. Aktifitasaktifitas tersebut dikenal dengan nama value chain. Penelitian ini bertujuan untuk menganalisis rantai nilai produk mebel rotan di Cirebon, menganalisa tahapan-tahapan yang harus dilakukan dalam membangun strategi kompetitif untuk produk mebel rotan di Cirebon, dan mendapatkan strategi kompetitif yang tepat untuk diterapkan oleh setiap pelaku rantai nilai produk mebel rotan di Cirebon sesuai dengan tahapan-tahapan yang dilakukan.

Dalam penyusunan penelitian ini, penulis akan membatasi permasalahan sebagai berikut:

1. Penelitian dilakukan dengan objek penelitian berupa produk furniture kursi rotan anyaman tipe single chair. Kursi rotan single chair ini dipilih sebagai objek penelitian dikarenakan tipe kursi ini merupakan tipe kursi yang sering dipesan dan mayoritas perusahaan yang menjadi objek penelitian pernah memproduksi kursi jenis ini.

2. Penelitian difokuskan pada bagian midstream.
3. Analisis value chain yang dilakukan adalah sampai tahap dimana perusahaan dapat menemukan strategi kompetitif sesuai dengan tahapan-tahapan yang dilakukan.

4. Survey yang dilakukan untuk menganalisis mebel rotan di kabupaten Cirebon mengambil sampel industri mebel yang termasuk anggota ASMINDO (Asosiasi Pengusaha Mebel Indonesia). Pemilihan anggota ASMINDO sebagai sampel karena perusahaan-perusahaan termasuk pada perusahaan yang masih bertahan dan aktif berproduksi.

5. Penelitian yang dilakukan dimulai dari segmen supplier dalam hal ini pengumpul bahan baku sampai ke buyer dalam hal ini adalah wholeseller.

Sedangkan asumsi yang digunakan dalam penelitian ini adalah biaya yang dijadikan acuan perhitungan tidak mengalami perubahan.

\section{METODOLOGI PENELITIAN}

Pada tahap awal penelitian dilakukan studi pendahuluan dengan melakukan studi literatur dan studi lapangan mengenai objek yang akan diteliti. Hasil dari studi pendahuluan ini dijadikan dasar dalam merumuskan masalah dan menentukan desain penelitian. Tahap selanjutnya yang dilakukan adalah proses pemetaan (mapping) rantai nilai produk mebel rotan single chair untuk mengetahui aliran input produk dan jasa dalam rantai nlai tersebut.

\section{Mapping}

Gambaran umum rantai nilai produk mebel rotan single chair dapat dilihat pada gambar 1.

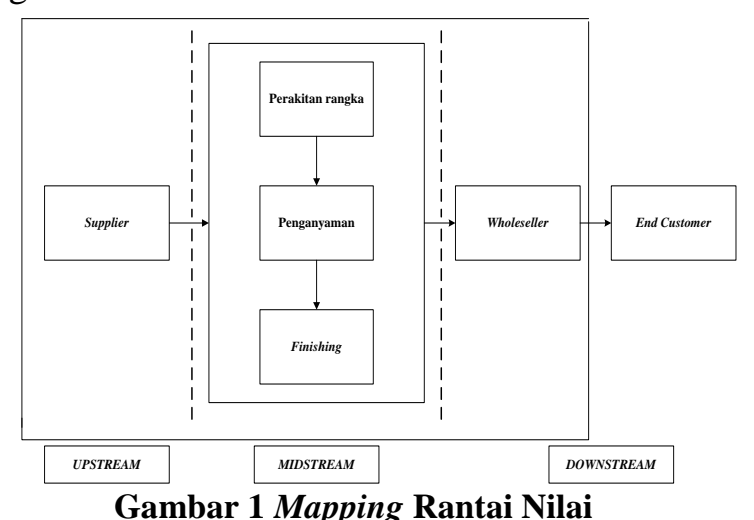


Setelah proses pemetaan dilakukan, dilakukan proses analisis finansial, analisis SWOT (strengths, weaknesses, opportunities, threats), analisis competitiveness diamond, dan analisis CSF (critical success factor). Metode yang digunakan untuk analisis finansial, analisis SWOT, dan analisis competitiveness diamond dengan melakukan wawancara. Metode wawancara ini menggunakan pendekatan kualitatif sehingga sampel yang digunakan tidak harus mewakili seluruh populasi, sampel memiliki pengetahuan yang cukup serta mampu menjelaskan keadaan sebenarnya tentang objek penelitian. Wawancara analisis finansial dilakukan dengan ketua Asmindo yang juga merupakan salah satu pengusaha rotan sehingga mengetahui kondisi perusahaanperusahaan anggota ASMINDO. Wawancara Diamond Porter dilakukan kepada perusahaan yang bersedia menjadi responden yaitu sebanyak 14 perusahaan yang merupakan anggota ASMINDO (Asosiasi Pengusaha Mebel Rotan Indonesia). Perusahaan-perusahaan ini termasuk yang masih aktif berproduksi dan memiliki karakteristik yang sama yaitu merupakan perusahaan skala menengah sehingga dapat mewakili kondisi perusahaan lain yang sejenis. Wawancara SWOT dilakukan kepada perwakilan dari Disperindag Kabupaten Cirebon yang menangani klaster mebel. Analisis CSF dilakukan dengan melakukan penyebaran kuesioner. Kuesioner CSF digunakan untuk mengetahui tingkat kepentingan dari masing-masing faktor penentu keberhasilan mebel rotan. Metode kuesioner menggunakan pendekatan kuantitatif. Penentuan jumlah sampel yang digunakan menggunakan batas minimal pengambilan sampel yaitu sebanyak 30 sampel. Oleh karena itu, banyaknya jumlah responden untuk kuesioner CSF ini adalah sebanyak 30 perusahaan anggota ASMINDO.

\section{Analisis Finansial}

Analisis finansial dilakukan dalam bentuk perhitungan margin dan blok kuantitatif. Analisis ini digunakan untuk mengetahui peran masing-masing segmen rantai nilai dalam memberikan kontribusi J@ TI Undip, Vol VIII, No 2, Mei 2013 terhadap penambahan nilai sehingga dapat dijadikan acuan untuk langkah analisis selanjutnya. Adapun contoh perhitungan margin yang djadikan sebagai acuan adalah seperti pada gambar 2 .

\begin{tabular}{|c|c|c|c|c|c|c|c|c|}
\hline \multirow[b]{2}{*}{ Value Chain Actor } & \multicolumn{3}{|c|}{ Costs } & \multirow{2}{*}{$\begin{array}{c}\text { Revenues } \\
\text { Unit } \\
\text { Price }\end{array}$} & \multicolumn{2}{|c|}{ Profits } & \multicolumn{2}{|c|}{ Margins } \\
\hline & $\begin{array}{l}\text { Unit Total } \\
\text { Cost }\end{array}$ & $\begin{array}{l}\text { Added Unit } \\
\text { Cosst" }\end{array}$ & $\begin{array}{l}\text { Yadded } \\
\text { Cost }\end{array}$ & & $\begin{array}{l}\text { Unit } \\
\text { Profit }\end{array}$ & $\begin{array}{l}\text { Y Total } \\
\text { Profits }\end{array}$ & $\begin{array}{l}\text { Unit } \\
\text { Margin }\end{array}$ & $\begin{array}{l}\text { Unit } \\
\text { Nargin }\end{array}$ \\
\hline Fomers & $A$ & . & Af & 6 & G.A & $(G \cdot A) \mid(K \cdot F)$ & 6 & 6 \\
\hline Assembleers & 6 & 8 & $B F$ & H & $H \cdot B \cdot G$ & $(H-B-G) \mid(K-F)$ & $H \cdot G$ & $H \cdot G$ \\
\hline Processors & $H+C$ & ( & (ff & I & I.CH & $\| \cdot \cdot \cdot H) /(K \cdot F)$ & H.H & I.H \\
\hline Troders & $1+0$ & 0 & OF & J & J.0.1 & $(\mid-D \cdot-1) \mid(K-A)$ & $\mu$ & $H$ \\
\hline Retailers & $J+E$ & t & Ef & k & K.E. & $(\mathrm{K} \cdot \mathrm{E} \cdot \mathrm{E}) \mid(\mathrm{K} \cdot \mathrm{F})$ & K.J & K.J \\
\hline Total & & $F=A+B+C+C+E+E$ & 100 & & K.F & 100 & K & $k$ \\
\hline $\begin{array}{l}\text { "Added unit } \\
\text { from the pre }\end{array}$ & $\begin{array}{l}\text { tst refer } \\
\text { us stage. }\end{array}$ & the added & & ch stage o & & & & \\
\hline
\end{tabular}

\section{Gambar 2 Perhitungan Margin Sumber : Department For International Development, 2008}

\section{Analisis SWOT}

Analisis SWOT yang digunakan menggunakan metode analisis kuantitatif sebagai titik awal untuk setiap strategi kompetitif, digunakan untuk melengkapi analisis blok kuantitatif. Analisis SWOT sangat berguna untuk memfokuskan diskusi awal tentang keadaan dari rantai nilai atau untuk melakukan brainstorming awal tentang potensi peluang dan resiko. Analisis SWOT digunakan dengan menganalisa Kekuatan (Strengths), Kelemahan (Weakness), Kesempatan (Opportunity), dan Ancaman (Threats) dari produk mebel rotan di kabupaten Cirebon.

\section{Analisis Competitiveness Diamond}

Porter's Competitiveness Diamond atau sering disebut "Porter Diamond" adalah model yang diciptakan oleh Michael Porter untuk membantu kita dalam memahami konsep keunggulan kompetitif (competitive advantage). Competitiveness Diamond merupakan alat yang paling teliti untuk mengevaluasi rantai nilai industri. Kerangka Competitiveness Diamond telah divalidasi oleh banyak studi analisis dan sekarang digunakan oleh industri dan pemerintahan dunia untuk menilai daya saing klaster 
industri dan untuk membangun strategi untuk meningkatkan daya saing. Model ini terdiri dari 4 pilar :

1. Faktor kondisi

2. Kondisi permintaan

3. Industri pendukung dan terkait

4. Strategi perusahaan dan pesaing

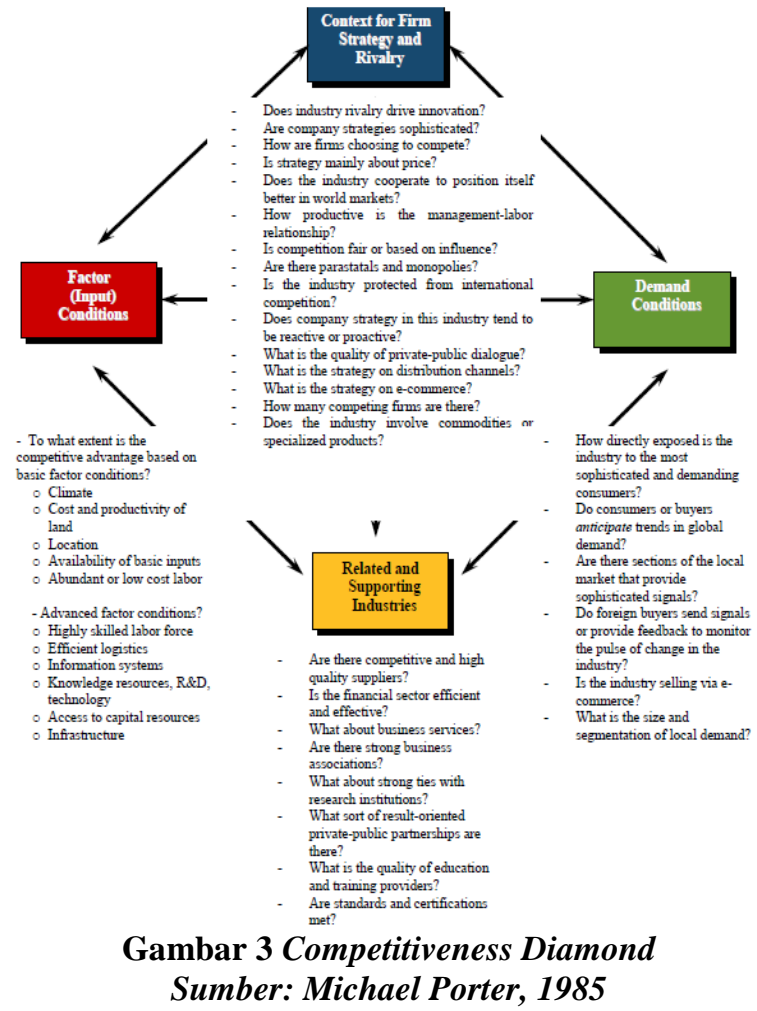

Berdasarkan penelitian yang dilakukan oleh Webber (2009) maka Diamond Porter yang dapat digunakan dalam analisis rantai nilai dapat menggunakan key question seperti yang ditunjukkan pada gambar 3 .

\section{Critical Success Factor (CSF)}

Berdasarkan studi literatur yang dilakukan, faktor-faktor yang merupakan critical success factor untukk industri mebel rotan adalah sebagai berikut:

1. Kualitas (Kaplinsky, 2002)

2. Desain (ITPC, 2009)

3. Harga (Kaplinsky, 2002)

4. Standar (UNIDO, 2003)

5. Delivery (UNIDO, 2003)

6. Fleksibilitas (Kaplinsky, 2002)

7. Promosi (ITPC, 2009)

\section{Penentuan Variabel CSF}

Berdasarkan studi literatur untuk penentuan faktor yang dilakukan maka variabel penelitian yang akan digunakan untuk menentukan tingkat kepentingan dari masing-masing faktor penentu keberhasilan industri mebel rotan di Kabupaten Cirebon dapat dilihat pada tabel 1.

\section{Pengujian Statistik Kuesioner}

- Uji Validitas Kuesioner

- Uji Reliabilitas Kuesioner

Tabel 1 Variabel Penelitian CSF

\begin{tabular}{|c|c|c|c|c|c|}
\hline No & Variabel & Definisi & Indikator & Pertanyaan & Sumber \\
\hline \multirow{3}{*}{1} & \multirow{3}{*}{ Kualitas } & \multirow{3}{*}{$\begin{array}{l}\text { Atribut produk yang } \\
\text { dipertimbangkan dari segi } \\
\text { manfaat fisiknya dalam hal ini } \\
\text { dilihat dari segi bahan baku. }\end{array}$} & Aman & $\begin{array}{l}\text { Menurut Anda apakah produk } \\
\text { yang aman bagi pemakai } \\
\text { merupakan hal yang penting? }\end{array}$ & \multirow{3}{*}{$\begin{array}{l}\text { Kaplinsky } \\
\text { (2002), } \\
\text { Widagdo } \\
\text { (2001) }\end{array}$} \\
\hline & & & Awet & $\begin{array}{l}\text { Menurut Anda apakah keawetan } \\
\text { produk merupakan hal yang } \\
\text { penting? }\end{array}$ & \\
\hline & & & $\begin{array}{l}\text { Ramah } \\
\text { lingkungan }\end{array}$ & $\begin{array}{l}\text { Menurut Anda apakah produk } \\
\text { yang ramah lingkungan } \\
\text { merupakan hal yang penting? }\end{array}$ & \\
\hline \multirow{3}{*}{2} & \multirow{3}{*}{ Design } & \multirow{3}{*}{$\begin{array}{lr}\text { Atribut produk yang } \\
\text { dipertimbangkan dari } & \text { segi } \\
\text { rancangan fisik produk } & \end{array}$} & Dekorasi & $\begin{array}{l}\text { Menurut Anda apakah dekorasi } \\
\text { produk yang sesuai dengan } \\
\text { pesanan merupakan hal yang } \\
\text { penting? }\end{array}$ & \multirow{3}{*}{$\begin{array}{l}\text { ITPC (2009), } \\
\text { Widagdo } \\
(2001)\end{array}$} \\
\hline & & & Warna & $\begin{array}{l}\text { Menurut Anda apakah } \\
\text { pemilihan warna produk yang } \\
\text { sesuai dengan pesanan } \\
\text { merupakan hal yang penting? }\end{array}$ & \\
\hline & & & Unik & $\begin{array}{l}\text { Menurut Anda apakah keunikan } \\
\text { bentuk produk merupakan hal } \\
\text { yang penting? }\end{array}$ & \\
\hline
\end{tabular}




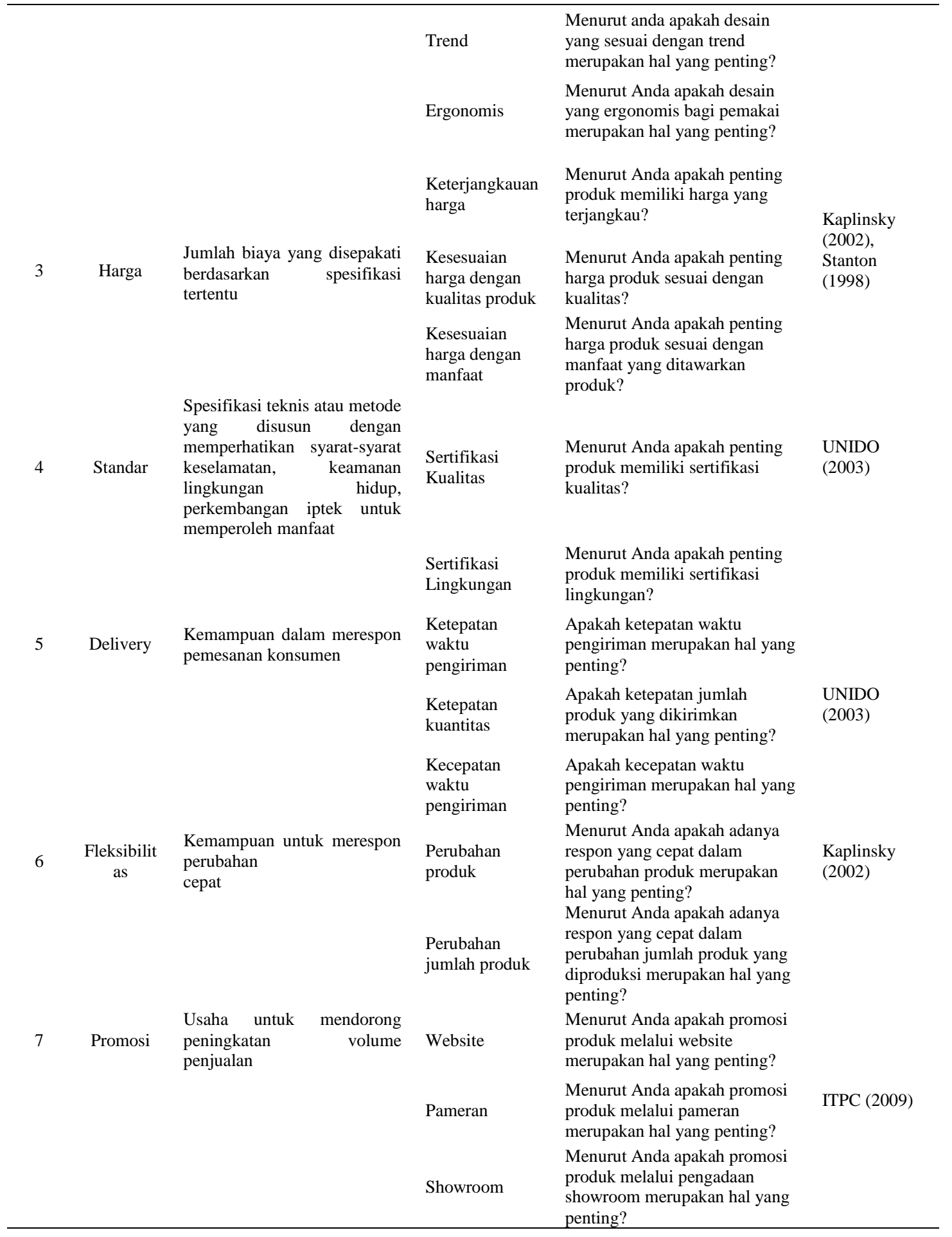

\section{ANALISIS DAN PEMBAHASAN}

Mapping Rantai Nilai

1. Upstream : Segmen upstream terdiri dari supplier-supplier baik bahan baku utama maupun bahan baku penunjang. Bahan baku utama untuk kursi rotan single chair ini terdiri rotan batang dan rotan cor. Rotan batang digunakan untuk pembuatan kerangka kursi, sedangkan rotan cor untuk anyaman. Bahan baku penunjang untuk kursi single chair ini antara lain paku, lem, staples, cat, thinner.

2. Midstream : Segmen midstream ini merupakan produsen dalam aktivitas 
rantai nilai. Di dalam segmen midstream terdapat proses-proses penambahan nilai yaitu proses pembuatan rangka, penganyaman, dan finishing.

3. Downstream : Segmen downstream merupakan pembeli dari finishing product yang dihasilkan dari perusahaan. Perusahaan membuat produk sesuai pesanan yang diinginkan oleh buyer. Yang dimaksud dengan buyer disini adalah wholeseller.

\section{Penambahan Nilai Tiap Segmen Rantai Nilai}

Margin adalah selisih dari total nilai (value) dan biaya total yang diperlukan untuk melakukan value activities seperti yang ditunjukkan pada tabel 2. Berdasarkan perhitungan margin pada tabel 2, maka dapat dilihat penambahan nilai dari masingmasing segmen dengan mapping rantai nilai seperti pada gambar 4 .

Pada tabel 2 dapat dilihat persentase penambahan nilai (\% added unit cost) terbesar ada pada segmen produksi sebesar $47,69 \%$. Sedangkan penambahan nilai terbesar kedua ada pada segmen wholeseller sebesar 33,69\%, dan penambahan nilai terkecil ada pada supplier rotan sebesar $18,62 \%$.

\section{SWOT (Strengths, Weaknesses, Opportunities, Threats)}

Perhitungan faktor internal SWOT yang terdiri dari faktor Strengths (Kekuatan) dan Weaknesses (Kelemahan) dapat dilihat pada tabel 3. Perhitungan faktor eksternal dapat dilihat pada tabel 4. Berdasarkan perhitungan SWOT kuantitatif pada tabel 3 dan 4, maka dibentuk matriks SWOT 4 kuadran yang didapatkan dari nilai Strength - Weaknesses (sumbu x) sebesar 0,14, dan Oportunities-Threats (sumbu y) sebesar 0,13 . Matriks tersebut dapat dilihat pada gambar 5.

Berdasarkan matriks SWOT, posisi perusahan rotan di Kab. Cirebon berada di sel atau kuadran II, menandakan sebuah organisasi yang kuat namun menghadapi tantangan yang besar. Rekomendasi strategi yang diberikan adalah diversifikasi strategi, artinya organisasi dalam kondisi mantap namun menghadapi sejumlah tantangan berat sehingga diperkirakan roda organisasi akan mengalami kesulitan untuk terus berputar bila hanya bertumpu pada strategi sebelumnya. Oleh karenanya, organisasi disarankan untuk segera memperbanyak ragam strategi taktisnya. Penerapannya dalam industri rotan di Cirebon khususnya untuk pengekspor adalah memproduksi untuk pasar lokal. Selain itu, perusahaan dapat melakukan merger dengan perusahaan yang atau dengan supplier rotan. Dengan merger ini, perusahaan dapat diuntungkan dalam ketersediaan bahan baku sehingga perusahaan tidak mengalami kesulitan dan dapat memilih kualitas yang diinginkan. Bila sedang tidak ada pesanan, perusahaan dapat menjadi supplier bagi perusahaan yang lain sehingga keuntungan bisa didapat walau tidak berproduksi.

Tabel 2 Perhitungan Margin Segmen-Segmen Rantai Nilai

\begin{tabular}{|c|c|c|c|c|c|c|c|c|}
\hline \multirow[b]{2}{*}{$\begin{array}{l}\text { Value } \\
\text { Chain } \\
\text { Actor }\end{array}$} & \multicolumn{3}{|c|}{ Cost } & \multirow{2}{*}{$\begin{array}{l}\text { Revenues } \\
\text { Unit Price } \\
\text { (Rp) }\end{array}$} & \multicolumn{2}{|c|}{ Profits } & \multicolumn{2}{|c|}{ Margins } \\
\hline & $\begin{array}{l}\text { Unit Total } \\
\text { Cost } \\
\text { (Rp) }\end{array}$ & $\begin{array}{l}\text { Added } \\
\text { Unit Cost } \\
\text { (Rp) }\end{array}$ & $\begin{array}{c}\% \\
\text { Added } \\
\text { Cost }\end{array}$ & & $\begin{array}{l}\text { Unit Profit } \\
\text { (Rp) }\end{array}$ & $\begin{array}{c}\% \\
\text { Total } \\
\text { Profits }\end{array}$ & $\begin{array}{l}\text { Unit Margin } \\
\text { (Rp) }\end{array}$ & $\begin{array}{c}\% \\
\text { Wholeseller } \\
\text { Price }\end{array}$ \\
\hline \multicolumn{9}{|l|}{ Supplier } \\
\hline Rotan & $187.727,27$ & & 20,65 & 206.500 & $18.772,73$ & 9,38 & 206.500 & 18,62 \\
\hline Produksi & $639.545,23$ & $433.045,23$ & 47,64 & $735.477,01$ & $95.931,78$ & 47,94 & $528.977,01$ & 47,69 \\
\hline \multirow[t]{2}{*}{ Wholeseller } & $1.023 .701,65$ & $288.224,64$ & 31,71 & $1.109 .088,90$ & $85.387,25$ & 42,67 & $373.611,89$ & 33,69 \\
\hline & & $908.997,14$ & 100,00 & & $200.091,76$ & 100,00 & $1.109 .088,90$ & 100,00 \\
\hline
\end{tabular}




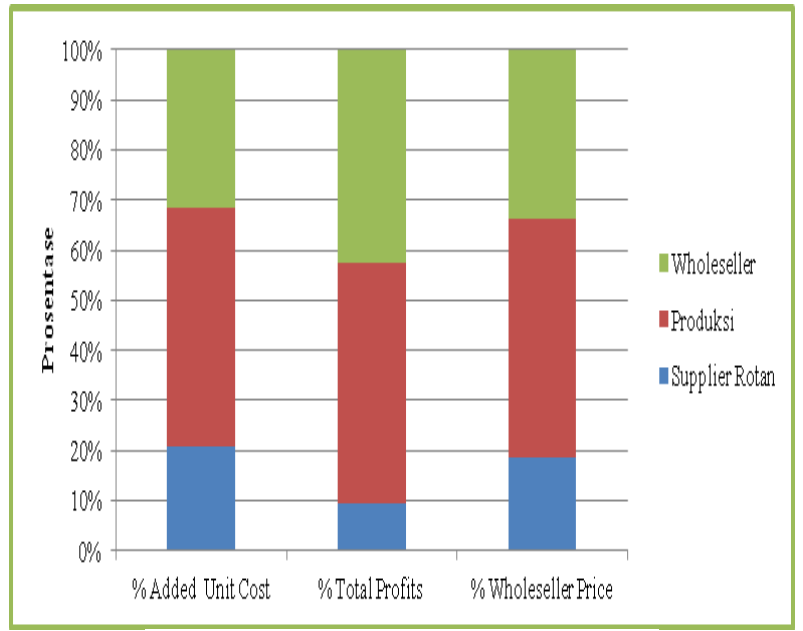

Gambar 4 Grafik Blok Kuantitatif

Tabel 3 Perhitungan Faktor Internal SWOT

\begin{tabular}{|c|c|c|c|c|c|}
\hline \multirow{2}{*}{ No } & Faktor Internal & \multirow{2}{*}{ Skor } & \multirow{2}{*}{$\begin{array}{l}\text { Nilai } \\
\text { Poin }\end{array}$} & \multirow{2}{*}{ Bobot } & \multirow{2}{*}{$\begin{array}{l}\text { Total } \\
(\text { Skor } \times \text { Bobot })\end{array}$} \\
\hline & Strength & & & & \\
\hline 1 & Banyaknya tenaga kerja ahli & 5 & 6 & 0,17 & 0,83 \\
\hline 2 & $\begin{array}{l}\text { Design furniture yang mengikuti trend pasar atau sesuai } \\
\text { dengan apa yang dikehendaki buyer }\end{array}$ & 4 & 7 & 0,19 & 0,78 \\
\hline 3 & Kualitas bahan baku dan anyaman yang diakui & 5 & 8 & 0,22 & 1,11 \\
\hline 4 & $\begin{array}{l}\text { Cirebon sebagai pusat industri rotan Indonesia sehingga } \\
\text { menarik supplier maupun buyer }\end{array}$ & 4 & 4 & 0,11 & 0,44 \\
\hline 5 & $\begin{array}{l}\text { Kebanyakan perusahaan sudah memiliki buyer yang } \\
\text { menjadi pelanggan }\end{array}$ & 3 & 2 & 0,06 & 0,17 \\
\hline 6 & Dukungan pemerintah & 5 & 5 & 0,14 & 0,69 \\
\hline 7 & Pasar sudah jelas & 4 & 3 & 0,08 & 0,33 \\
\hline \multirow[t]{3}{*}{8} & $\begin{array}{l}\text { Perusahaan banyak tersebar di dalam satu kawasan } \\
\text { (klaster) }\end{array}$ & 4 & 1 & 0,03 & 0,11 \\
\hline & \multicolumn{2}{|l|}{$\begin{array}{ll} & \text { Total } \\
\end{array}$} & 36 & 1,00 & 4,47 \\
\hline & Weakness & & & & \\
\hline 1 & $\begin{array}{l}\text { Bahan baku yang diekspor sehingga memberikan } \\
\text { keuntungan kepada negara pesaing untuk memiliki } \\
\text { bahan baku berkualitas }\end{array}$ & 5 & 3 & 0,50 & 2,50 \\
\hline 2 & $\begin{array}{l}\text { Bahan baku terletak di luar daerah, meningkatkan biaya } \\
\text { transportasi dan pajak }\end{array}$ & 3 & 1 & 0,17 & 0,50 \\
\hline 3 & Inovasi produk berjalan lambat & 4 & 2 & 0,33 & 1,33 \\
\hline & Total & & 6 & 1,00 & 4,33 \\
\hline & Selisih total strength-total weakness & & & & 0,14 \\
\hline
\end{tabular}

Tabel 4 Perhitungan Faktor Eksternal SWOT

\begin{tabular}{|c|c|c|c|c|c|}
\hline \multirow{2}{*}{ No } & Faktor Eksternal & \multirow{2}{*}{ Skor } & \multirow{2}{*}{$\begin{array}{l}\text { Nilai } \\
\text { Poin }\end{array}$} & \multirow{2}{*}{ Bobot } & \multirow{2}{*}{$\begin{array}{c}\text { Total } \\
\text { (Skor x Bobot) }\end{array}$} \\
\hline & Opportunities & & & & \\
\hline 1 & $\begin{array}{l}\text { Ekspor produk furniture ke luar negeri sehingga } \\
\text { memungkinkan mencapai pangsa pasar dunia. }\end{array}$ & 4 & 2 & 0,20 & 0,80 \\
\hline 2 & Marketing via $e$-commerce. & 4 & 3 & 0,30 & 1,20 \\
\hline 3 & $\begin{array}{l}\text { Banyaknya pengusaha rotan di Cirebon sehingga } \\
\text { menarik buyer karena image Cirebon sebagai pusat } \\
\text { industri rotan Indonesia }\end{array}$ & 3 & 1 & 0,40 & 1,20 \\
\hline \multirow[t]{3}{*}{4} & Mengikutsertakan diri dalam pameran-pameran & 5 & 4 & 0,10 & 0,50 \\
\hline & Total & & 10 & 1,00 & 3,70 \\
\hline & Threats & & & & \\
\hline 1 & Kebijakan pemerintah yang membuka kran ekspor & 5 & 2 & 0,33 & 1,67 \\
\hline 2 & Persaingan antar produsen dunia & 5 & 3 & 0,17 & 0,83 \\
\hline \multirow[t]{3}{*}{3} & Ekspor bahan baku ilegal ke negara pesaing & 3 & 1 & 0,50 & 1,50 \\
\hline & Total & & 6 & 1,00 & 4,00 \\
\hline & Selisih total opportunities - total threats & & & & $-0,30$ \\
\hline
\end{tabular}




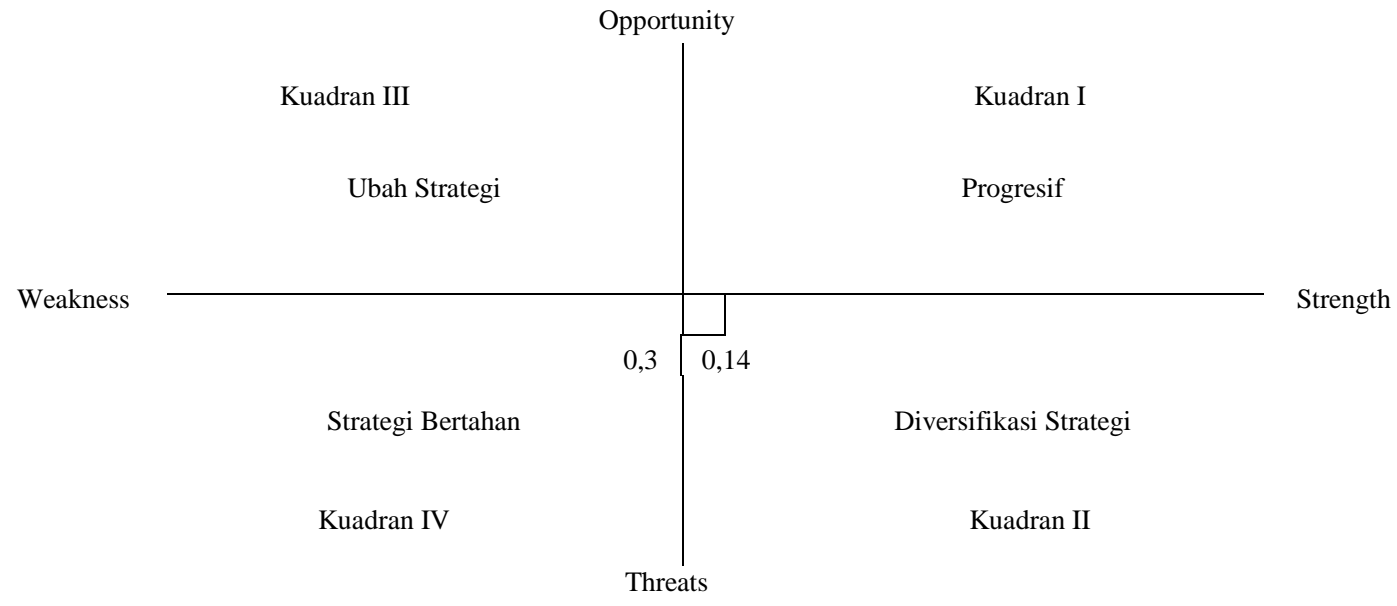

Gambar 5 Matriks SWOT 4 Kuadran

\section{Competitiveness Diamond \\ Analisis Faktor Kondisi}

Industri-industri rotan di Cirebon ini memiliki keuntungan dalam hal lokasi, ketersediaan sumber daya manusia terampil, dan juga infrastruktur yang menunjang. Kesulitan perusahaan terutama dari segi bahan baku adalah biaya yang dikeluarkan lebih tinggi karena bahan baku didapat dari tangan kedua bahkan mungkin tangan ketiga dan tidak langsung dari petani. Oleh karena itu sebaiknya pemasok sebaiknya memiliki anak perusahaan di tempat tersedianya bahan baku.

\section{Analisis Kondisi Permintaan}

Berdasarkan data hasil wawancara, kondisi permintaan produk rotan di kawasan industri Kabupaten Cirebon sangat bergantung pada buyer yang sudah menjadi langganan perusahaan. Strategi yang dapat dilakukan berdasarkan faktor permintaan adalah mempertahankan hubungan dengan buyer terutama buyer langganan. Selain itu, perusahaan juga sebaiknya aktif dalam melakukan inovasi untuk meningkatkan kualitas produk yang dihasilkan, dan setiap inovasi ini diinformasikan kepada buyer untuk menarik lebih banyak pesanan.

\section{Analisis Strategi Perusahaan dan Pesaing}

Strategi perusahaan terutama adalah kualitas. Sedangkan strategi negara pesaing adalah harga. Perusahaan-perusahaan di Kabupaten Cirebon biasanya melakukan solusi untuk menekan harga jual dengan adanya kesepakatan penggunaan bahan baku

J@TI Undip, Vol VIII, No 2, Mei 2013 yang digunakan dan kualitas yang dihasilkan. Sehingga terjadi kesepakatan harga yang disetujui oleh buyer sesuai dengan kualitas yang dihasilkan perusahaan.

\section{Analisis Industri Pendukung dan Terkait \\ Berdasarkan analisis industri terkait dan pendukung, strategi yang dapat dilakukan adalah kerjasama dengan asosiasi dalam hal ini ASMINDO dengan pemerintah terutama dalam hal marketing untuk menambah jaringan buyer dan meningkatkan permintaan. Strategi marketing yang dapat dilakukan salah satunya adalah dengan mengikutsertakan produk rotan pada pameran-pameran.}

\section{Critical Success Factor (CSF)}

Berdasarkan hasil data kuesioner perusahaan dan buyer selanjutnya dilakukan perhitungan rata-rata nilai dari masingmasing faktor CSF sehingga dapat dilihat tingkat kepentingannya. Nilai rata-rata masing-masing faktor CSF dapat dilihat pada tabel 5. Setelah didapatkan rata-rata nilai faktor CSF berdasarkan persepsi perusahaan, selanjutnya dibuat spider web pada gambar 6 .

Tabel 5 Rata-Rata Nilai CSF

\begin{tabular}{|c|c|c|c|}
\hline \multirow[b]{2}{*}{ Item CSF } & \multicolumn{2}{|c|}{ Rata-Rata Nilai } & \multirow{2}{*}{$\begin{array}{l}\text { Gap Rata- } \\
\text { Rata Nilai }\end{array}$} \\
\hline & $\begin{array}{l}\text { Persepsi } \\
\text { Perusahaan }\end{array}$ & $\begin{array}{l}\text { Persepsi } \\
\text { Buyer }\end{array}$ & \\
\hline Kualitas & 4,67 & 4,73 & 0,07 \\
\hline Design & 4,50 & 4,47 & 0,03 \\
\hline Harga & 4,27 & 4,50 & 0,23 \\
\hline Standar & 3,72 & 3,73 & 0,02 \\
\hline Delivery & 4,73 & 4,72 & 0,01 \\
\hline Fleksibilitas & 4,27 & 4,37 & 0,10 \\
\hline Promosi & 3,86 & 3,94 & 0,09 \\
\hline
\end{tabular}




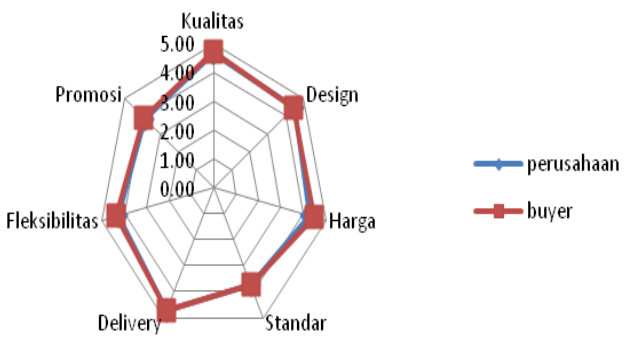

Gambar 6 Spider Web

Berdasarkan data hasil CSF dan gambar spider web CSF terlihat bahwa antara perusahaan dengan buyer sudah cukup memiliki perspektif yang sama terhadap tingkat kepentingan faktor-faktor penentu keberhasilan produk rotan ini.

\section{Rekomendasi Strategi}

Berdasarkan analisis finansial, SWOT, Competitiveness Diamond, dan CSF yang dilakukan, berikut rekomendasi dari keempat analisis tersebut maka strategi yang dapat dilakukan oleh masing-masing segmen di upstream, midstream, maupun downstream dapat dilihat pada tabel 6 .

Tabel 6 Rekomendasi Strategi

\begin{tabular}{|c|c|c|c|}
\hline Segmen & Kebijakan & Analisis & Rekomendasi Strategi \\
\hline Upstream & $\begin{array}{l}\text { Memperluas jaringan dengan } \\
\text { mendirikan anak perusahaan } \\
\text { di tempat tersedia bahan baku }\end{array}$ & $\begin{array}{l}\text { Competitiveness } \\
\text { Diamond }\end{array}$ & $\begin{array}{l}\text { Pemasok bahan baku dapat memperluas jaringan } \\
\text { dengan memiliki anak perusahaan di tempat } \\
\text { tersedianya bahan baku. Sehingga pemasok dapat } \\
\text { langsung mendapatkan bahan baku rotan langsung dari } \\
\text { petani untuk kemudian dikirimkan langsung ke } \\
\text { perusahaan induk yang ada di dalam kota. } \\
\text { Supplier dapat melakukan merger dengan perusahaan } \\
\text { yang memproduksi produk jadi. Sehingga keuntungan } \\
\text { yang didapatkan diharapakan bisa lebih besar karena } \\
\text { terjadi efisiensi biaya dan waktu. }\end{array}$ \\
\hline Midstream & $\begin{array}{l}\text { Penerapan upah tenaga kerja } \\
\text { per rate } \\
\text { Menerapkan sistem inventory } \\
\text { Penambahan alokasi dana } \\
\text { promosi dan merambah pasar } \\
\text { lokal } \\
\text { Prioritas buyer langganan } \\
\text { Menerapkan sistem diskon } \\
\text { untuk buyer langganan atau } \\
\text { buyer yang memesan dalam } \\
\text { volume besar } \\
\text { Sharing informasi dan inovasi } \\
\text { dengan buyer } \\
\text { Kerjasama dengan asosiasi } \\
\text { dan pemerintah dalam } \\
\text { marketing produk } \\
\text { Melakukan merger dengan } \\
\text { supplier atau perusahaan lain } \\
\text { Menjaga ketepatan waktu } \\
\text { maupun kuantitas pengiriman } \\
\text { dan memiliki fleksibilitas } \\
\text { tinggi dalam kualitas dan } \\
\text { harga } \\
\text { Segmentasi pasar berdasarkan } \\
\text { tipe buyer }\end{array}$ & $\begin{array}{l}\text { Finansial } \\
\text { Finansial } \\
\text { Finansial, } \\
\text { Competetiveness } \\
\text { Diamond } \\
\text { Competitiveness } \\
\text { Diamond } \\
\text { Competitiveness } \\
\text { Diamond } \\
\text { Competitiveness } \\
\text { Diamond, CSF } \\
\text { Competitiveness } \\
\text { Diamond }\end{array}$ & $\begin{array}{l}\text { Perusahaan menerapkan sistem upah per rate artinya } \\
\text { berdasarkan jumlah unit yang dihasilkan. Selain itu } \\
\text { perusahaan sebaiknya memiliki inventory bahan baku } \\
\text { yang sering digunakan melihat pola permintaan masa } \\
\text { lalu. } \\
\text { Dalam hal promosi perusahaan dapat memaksimalkan } \\
\text { fungsi website dengan mengiklankan website itu } \\
\text { sendiri di website-website lain yang memungkinkan } \\
\text { dilihat oleh orang banyak. Selain itu promosi juga } \\
\text { dilakukan untuk pasar lokal untuk mengantisipasi } \\
\text { sepinya permintaan ekspor. Promosi ini pun dapat } \\
\text { dilakukan dengan memaksimalkan fungsi asosiasi dan } \\
\text { juga kerjasama dengan pemerintah seperti dalam hal } \\
\text { pengadaan pameran-pameran. } \\
\text { Perusahaan sebaiknya dapat melakukan segmentasi } \\
\text { terlebih dahulu untuk karakteristik buyer sehingga } \\
\text { terjadi penyesuaian antara kualitas dengan harga, } \\
\text { artinya perusahaan harus memiliki tingkat fleksibilitas } \\
\text { yang tinggi. Perusahaan juga dapat membuat katalog } \\
\text { berdasarkan jenis dan kualitas bahan baku dan design } \\
\text { untuk memudahkan kesepakatan antara perusahaan } \\
\text { dengan buyer. } \\
\text { Dalam menjaga hubungan baik dengan buyer, } \\
\text { perusahaan selain menjaga kepercayaan buyer } \\
\text { perusahaan dapat ikut serta aktif dalam pengembangan } \\
\text { produk sehingga desain tidak hanya bergantung pada } \\
\text { buyer saja tetapi perusahaan dapat melakukan } \\
\text { intervensi berdasarkan kapasitas perusahaan dalam } \\
\text { melakukan modifikasi produk. Oleh karena itu } \\
\text { perusahaan sebaiknya memaksimalkan fungsi R\&D } \\
\text { untuk inovasi produk. Kerjasama yang baik juga } \\
\text { sebaiknya dilakukan dengan pihak supplier atau } \\
\text { perusahaan dapat melakukan merger dengan supplier } \\
\text { selain agar terjadi efisiensi biaya dan waktu, pada saat } \\
\text { permintaan sepi perusahaan juga dapat berfungsi } \\
\text { sebagai supplier bahan baku untuk perusahaan lain }\end{array}$ \\
\hline
\end{tabular}




\begin{tabular}{|c|c|c|c|}
\hline Segmen & Kebijakan & Analisis & Rekomendasi Strategi \\
\hline \multirow{6}{*}{ Downstream } & Menurunkan harga produk & Finansial & \multirow{6}{*}{$\begin{array}{l}\text { Strategi untuk buyer dalam hal ini } \\
\text { wholeseller sebaiknya wholeseller } \\
\text { dapat menurunkan harga produk. } \\
\text { Dengan prosentase keuntungan yang } \\
\text { tinggi, penambahan nilai yang tidak } \\
\text { terlalu banyak, wholeseller dapat } \\
\text { memaksimalkan promosi website, } \\
\text { memperluas jaringan promosi dengan } \\
\text { iklan-iklan pada jejaring sosial, blog, } \\
\text { ataupun website lain yang memiliki } \\
\text { banyak pengunjung seperti promosi } \\
\text { yang dilakukan oleh pihak perusahaan. } \\
\text { Kerjasama yang sangat baik dijaga } \\
\text { antara perusahaan dengan wholeseller } \\
\text { agar produk yang dihasilkan sesuai } \\
\text { dengan apa yang diinginkan oleh kedua } \\
\text { belah pihak. } \\
\text { Pihak wholeseller juga sebaiknya } \\
\text { menerapkan sistem diskon maupun } \\
\text { bebas ongkos kirim pada masa-masa } \\
\text { tertentu untuk menarik lebih banyak } \\
\text { konsumen dan juga sebagai ajang } \\
\text { promosi produk itu sendiri. }\end{array}$} \\
\hline & Memaksimalkan promosi & Finansial & \\
\hline & $\begin{array}{l}\text { Menerapkan sistem diskon atau bebas } \\
\text { ongkos kirim kepada konsumen untuk } \\
\text { masa tertentu }\end{array}$ & $\mathrm{CSF}$ & \\
\hline & $\begin{array}{l}\text { Menjaga hubungan baik dengan pihak } \\
\text { perusahaan di midstream }\end{array}$ & CSF & \\
\hline & & & \\
\hline & Kerjasama dalam inovasi produk & CSF & \\
\hline
\end{tabular}

\section{KESIMPULAN}

Berdasarkan hasil pengolahan dan analisis data, bahwa rantai nilai industri rotan di Kab. Cirebon terdiri dari segmen upstream (supplier-supplier bahan baku, segmen midstream yang merupakan produsen dan juga segmen downstream yang terdiri dari buyer dalam hal ini adalah wholeseller). Tahapan dalam menganalisis rantai nilai adalah dengan melakukan analisis finansial, analisis SWOT, analisis competitiveness diamond porter, dan analisis CSF (critical success factors). Strategi yang dapat diterapkan setiap pelaku rantai nilai produk mebel rotan di Kab. Cirebon adalah :

Rekomendasi strategi yang diberikan kepada supplier adalah memperluas jaringan dengan mendirikan anak perusahaan di tempat tersedia bahan baku dan melakukan merger dengan perusahaan.

Rekomendasi strategi yang diberikan kepada perusahaan adalah menerapkan upah tenaga kerja per unit produk yang dihasilkan, pengalokasian dana untuk promosi, memaksimalkan penggunaan website, memaksimalkan fungsi $\mathrm{R} \& \mathrm{D}$, memprioritaskan buyer langganan, sharing informasi dan inovasi dengan buyer, memiliki fleksibilitas yang tinggi dalam hal kualitas dan harga, bekerjasama dengan asosiasi dan pemerintah dalam kegiatan pameran, dan melakukan merger dengan perusahaan lain ataupun dengan supplier.
Rekomendasi strategi yang diberikan kepada wholeseller adalah dengan menurunkan harga produk, memaksimalkan kegiatan promosi, penetapan diskon, dan menjaga hubungan baik dengan perusahaan yang sudah menjadi kepercayaan.

\section{DAFTAR PUSTAKA}

1. Department For International Development, Making Value Chains Work Better For The Poor, London, 2008.

2. Kaplinsky, Raphael dan Mike Morris, $A$ Handbook For Value Chain Research, Institute of Development Studies, 2002.

3. Porter, Michael E., Competitive Advantage: Creating and Sustaining SuperiorPerformance, N. York: The Free Press, 1985.

4. Webber, Martin, Using Value Chain Approaches in Agribusiness and Agriculture, The World Bank Group, 2009.

5. _ http://dishut.jabarprov.go.id diunduh 23 Juli 2011.

6. _ http://itpchamburg.de diunduh 25 Juli 2011.

7. _ www.sincerity1234.com diunduh 25 Juli 2011. 